\title{
KEY FACTS ON CORPORATE FOUNDATIONS
}

\section{Outlook for Corporate Foundation Giving}

Corporate foundations reduced their giving by an estimated 3.3 percent in 2009-a much smaller decline than those reported for independent and community foundations. Grant dollars slipped to $\$ 4.4$ billion, falling below the record $\$ 4.6$ billion posted in $2008^{1}$ but matching the level of corporate foundation giving reported in 2007. The relatively less severe reduction in giving reported by corporate foundations may come as a surprise given both the across-the-board reductions in corporate earnings and the large share of giving - typically about one-quarter-historically accounted for by foundations established by companies in the banking and finance sector. This finding suggests that, as with other types of foundations, corporate foundations were also making exceptional efforts to minimize reductions in giving during the economic crisis, despite the need to cut expenses as profits slumped. It may also reflect in part the surprisingly rapid return to profitability of several major firms in the banking and finance industry.

Looking ahead, three out of five (60 percent) corporate foundations responding to the Foundation Center's annual forecasting survey expect to either increase or maintain their giving in $2010 .^{2}$

1 Figures exclude giving by corporate operating foundations. For more details see "The Impact of Foundations Established by Pharmaceutical Corporations."

2 For more details see S. Lawrence and R. Mukai, Foundation Growth and Giving Estimates: Current Outlook, The Foundation Center, New York, 2010.

Three out of five surveyed corporate foundations expect to increase or maintain giving in 2010

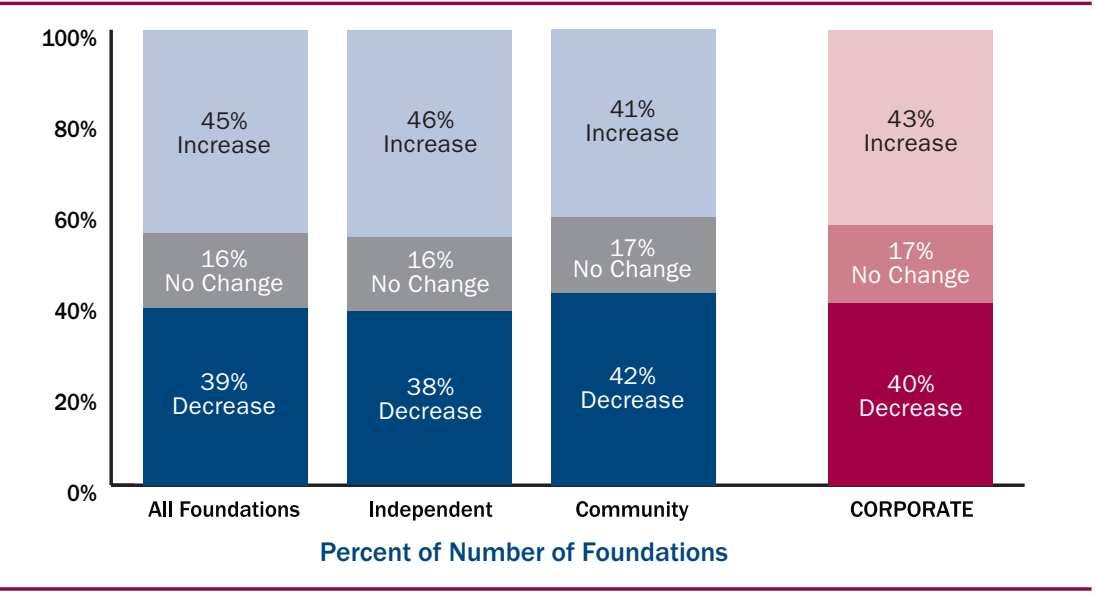

Note: A total of 1,180 foundations responded to this question, including 883 independent, 192 community, and 105 corporate foundations. Due to rounding, figures may not add up to 100 percent.

\section{\$4.4 billion}

Estimated giving by corporate foundations

in 2009

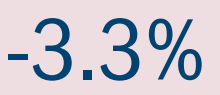

Estimated decrease in corporate foundation giving between 2008 and 2009

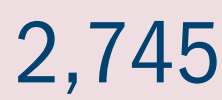

Number of

grantmaking corporate foundations in 2008

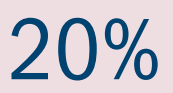

Share of corporate foundations reporting more than $\$ 1$ million

in giving in 2008

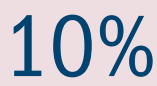

Corporate foundation giving as a share of all foundation giving in 2008 


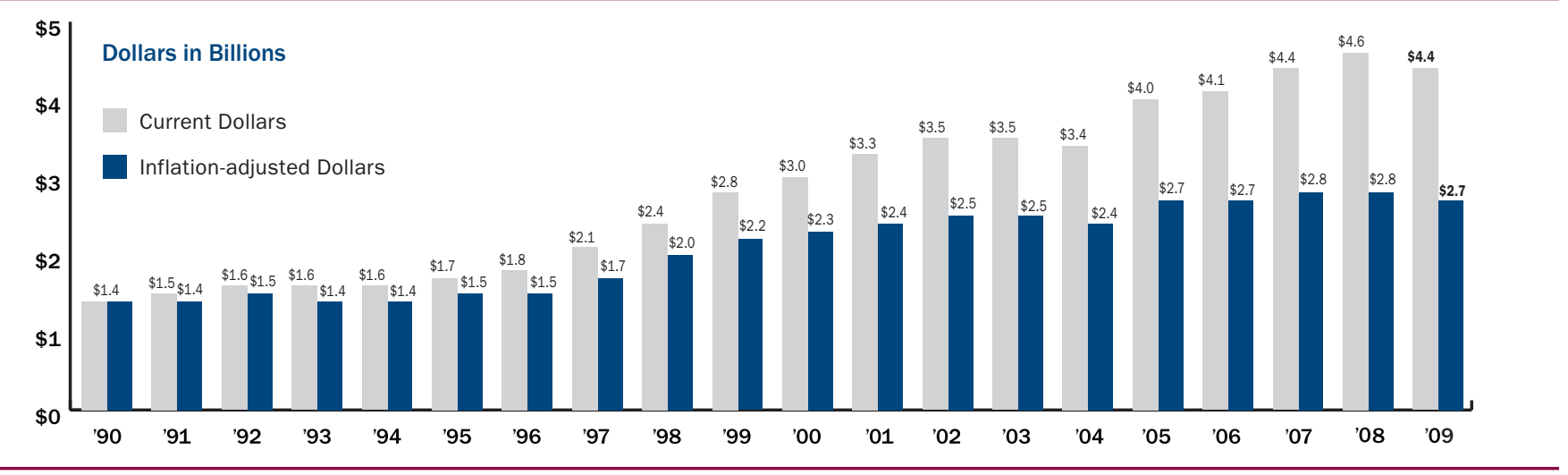

Note: Figure estimated for 2009. Excludes giving by corporate operating foundations.

Accounting for inflation, corporate foundations reported slower cumulative growth in giving than other types of foundations since 1990

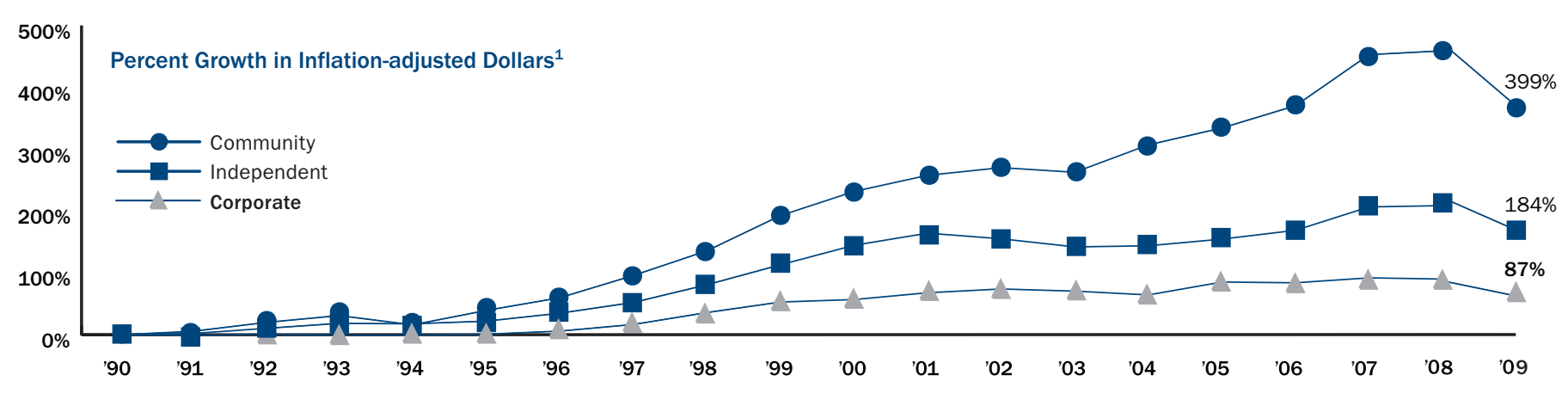

1Percent change in constant 1990 dollars based on annual average Consumer Price Index, all urban consumers (Source: U.S. Department of Labor, Bureau of Labor Statistics, as of March 2010).

Corporate foundation giving accounted for about one-tenth of all giving in 2009

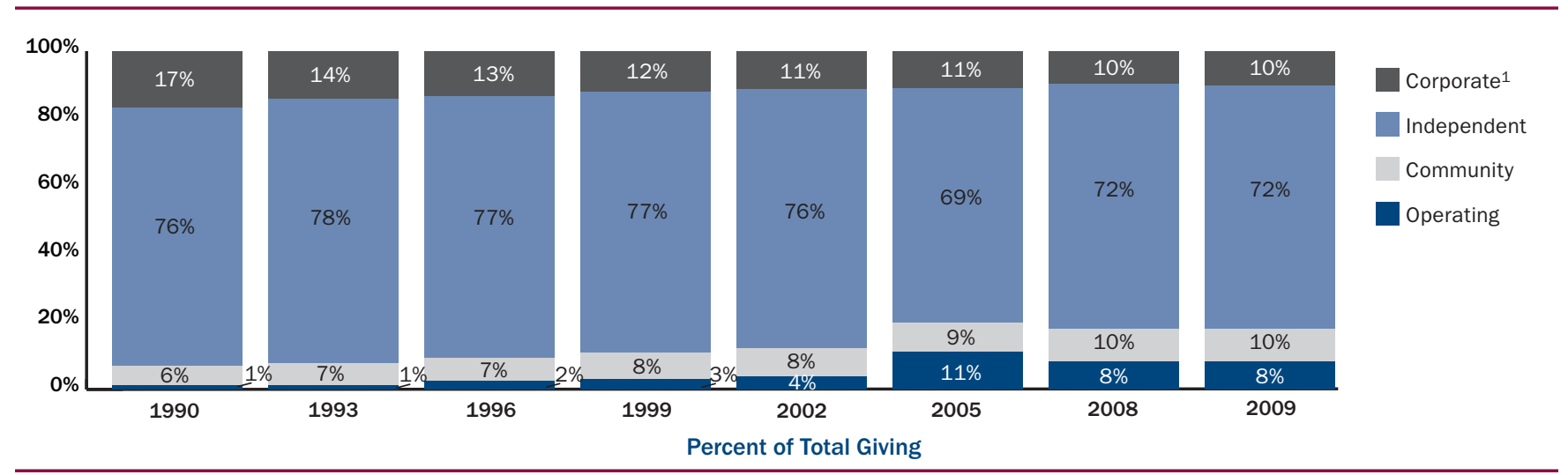

Note: Figures estimated for 2009; due to rounding, figures may not add up.

${ }^{1}$ Excludes giving by corporate operating foundations. 


\section{Corporate Foundation Giving Patterns, 2008}

Compared to community and independent foundations, the larger corporate foundations included in the Foundation Center's 2008 grants sample ${ }^{1}$ were more likely to allocate funding for public affairs/society benefit. Much of the larger share of support for public affairs/society benefit reflected giving for philanthropy and voluntarism, including federated funds. By types of support, corporate foundations favored program support, followed by general operating support-consistent with giving patterns of community foundations.

${ }^{1}$ The Foundation Center's 2008 grants sample database includes all of the grants of $\$ 10,000$ or more awarded by 1,490 of the largest U.S. foundations, including 184 corporate foundations. The overall sample accounted for roughly half of grant dollars awarded by the more than 75,000 grantmaking U.S. foundations.
Education and Human Services were the top priorities of corporate foundations in 2008

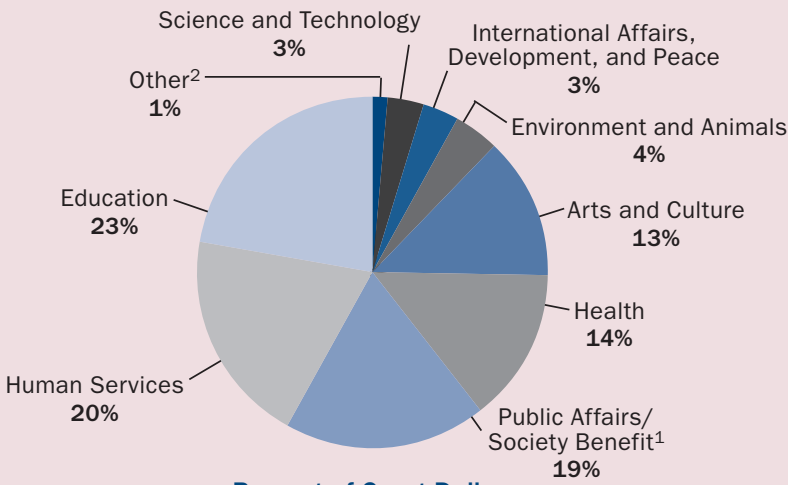

Percent of Grant Dollars

Note: Based on grants of $\$ 10,000$ or more awarded by a sample of 184 larger corporate foundations. Excludes giving by corporate operating foundations; due to rounding, figures may not add up.

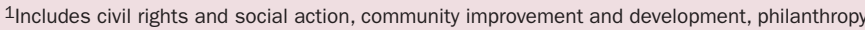
and voluntarism, and public affairs.

2Includes religion and the social sciences.

Education was a top priority of corporate foundations in three of the four major regions in 2008

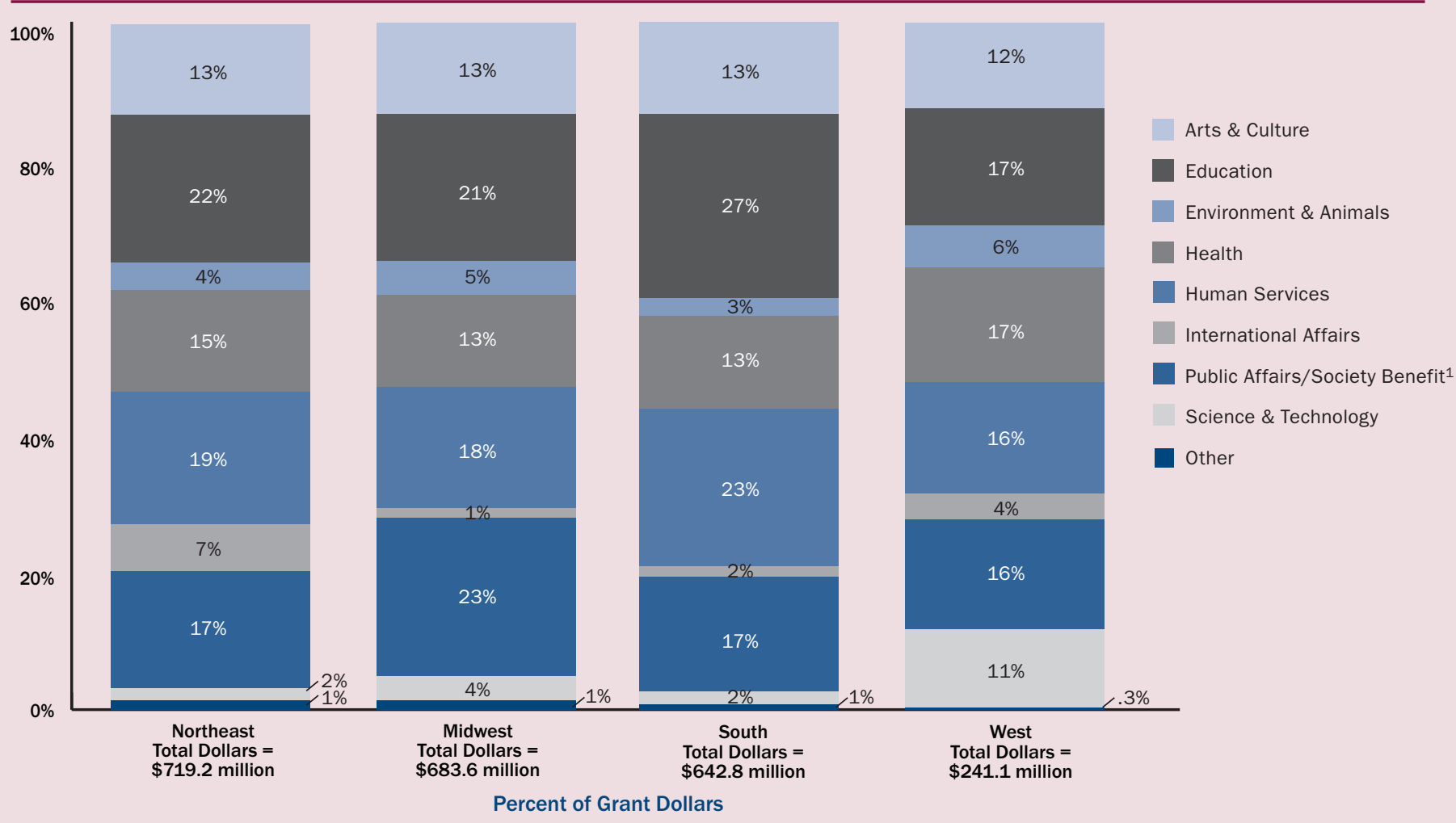

Note: Based on a sample of 184 larger corporate foundations. Excludes giving by corporate operating foundations; due to rounding, figures may not add up.

1 Includes civil rights and social action, community improvement and development, philanthropy and voluntarism, and public affairs. 


\section{Corporate Foundation Giving Patterns, 2008, continued}

Corporate foundations provided larger shares of funding for public affairs/society benefit and science and technology than other foundations in 2008

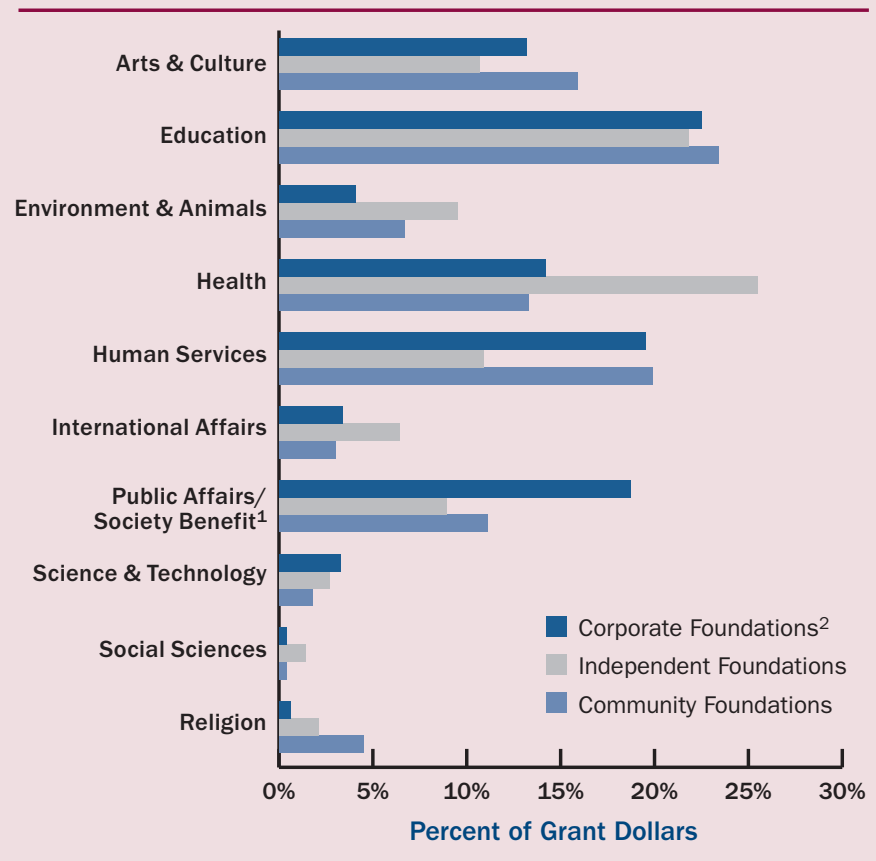

Note: Based on a sample of 1,490 larger foundations.

1 Includes civil rights and social action, community improvement and development,

philanthropy and voluntarism, and public affairs.

${ }^{2}$ Excludes giving by corporate operating foundations.
More than half of all corporate grants provided program or operating support in 2008*

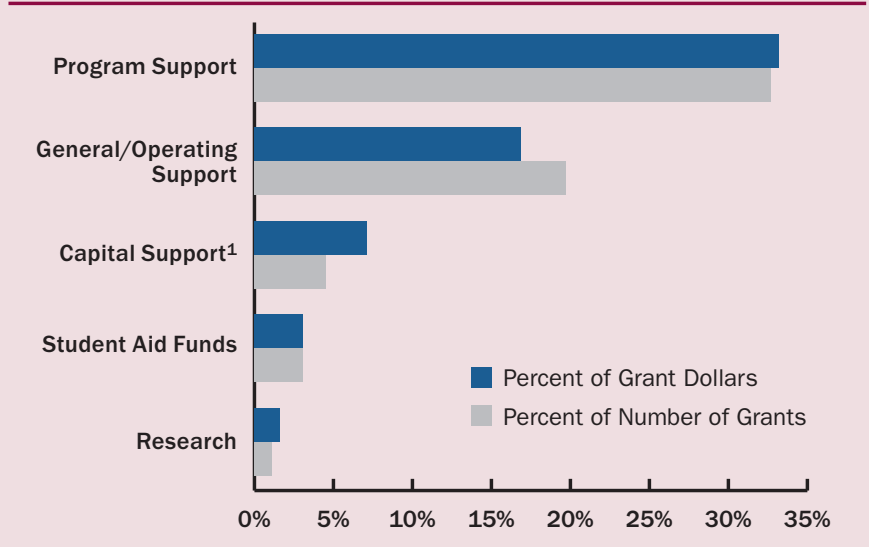

Note: Based on a sample of 184 larger corporate foundations. Nearly half of grant dollars and grants could not be identified by type of support.

*Excludes giving by corporate operating foundations.

${ }^{1}$ Includes endowment funds.

\section{Summary 2008 Statistics for Corporate Foundations}

\section{Change in Corporate Foundations, 2007 to 2008}

\begin{tabular}{lrrr}
\hline & $\mathbf{2 0 0 7}$ & $\mathbf{2 0 0 8}$ & $\%$ Change \\
\hline No. of Foundations & 2,498 & 2,745 & 9.9 \\
Total Giving & $\$ 4,397,201$ & $\$ 4,570,362$ & 3.9 \\
Total Assets & $\$ 21,923,610$ & $\$ 20,335,165$ & -7.2 \\
Gifts Received & $\$ 4,417,855$ & $\$ 4,615,135$ & 4.5 \\
\hline
\end{tabular}

Note: Dollars in thousands. Excludes giving by corporate operating foundations.
Corporate foundation giving represented about one-tenth of total foundation giving in $\mathbf{2 0 0 8}$

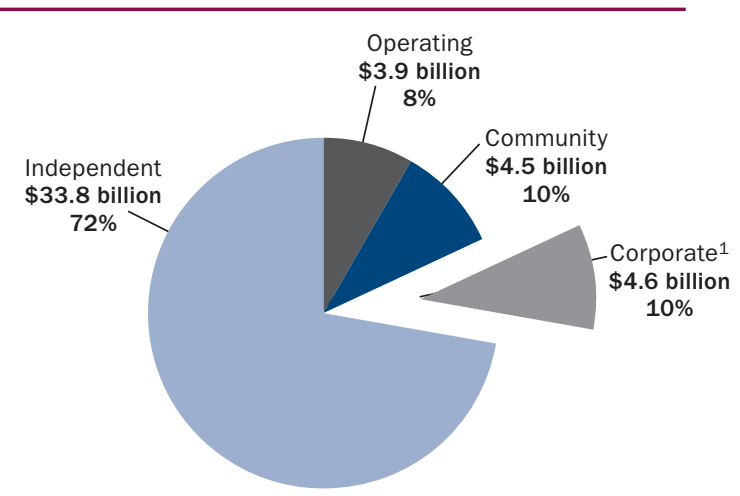

Total Giving $=\$ 46.8$ billion

Note: Based on total giving by 75,595 grantmaking private and community foundations.

${ }^{1}$ Excludes giving by corporate operating foundations. 


\section{Summary 2008 Statistics for Corporate Foundations, continued}

Top 25 Corporate Foundations by Total Giving, 2008*

\begin{tabular}{|c|c|c|c|c|c|}
\hline Foundation & State & $\begin{array}{l}\text { Total } \\
\text { Giving }^{1}\end{array}$ & $\begin{array}{c}\text { Qualifying } \\
\text { Distributions }^{2}\end{array}$ & Assets & Fiscal Date \\
\hline 1. Sanofi-Aventis Patient Assistance Foundation & NJ & $\$ 260,740,827$ & $260,740,827$ & $\$ 0$ & $12 / 31 / 2008$ \\
\hline 2. Bank of America Charitable Foundation & NC & $204,502,934$ & $210,201,689$ & $18,869,006$ & $12 / 31 / 2008$ \\
\hline 3. GE Foundation & Ст & $97,617,185$ & $99,399,629$ & 344,667 & $12 / 31 / 2008$ \\
\hline 4. Wachovia Wells Fargo Foundation & NC & $93,233,111$ & $97,178,745$ & $174,919,961$ & $12 / 31 / 2008$ \\
\hline 5. Citi Foundation & NY & $91,937,738$ & $91,952,293$ & $58,413,548$ & $12 / 31 / 2008$ \\
\hline 6. ExxonMobil Foundation & TX & $80,338,227$ & $80,639,595$ & $55,833,678$ & $12 / 31 / 2008$ \\
\hline 7. JPMorgan Chase Foundation & NY & $77,145,399$ & $77,145,399$ & $77,079,283$ & $12 / 31 / 2008$ \\
\hline 8. Wells Fargo Foundation & $\mathrm{CA}$ & $66,702,936$ & $66,702,936$ & $315,310,349$ & $12 / 31 / 2008$ \\
\hline 9. Verizon Foundation & NJ & $56,953,706$ & $65,582,514$ & $253,726,601$ & $12 / 31 / 2008$ \\
\hline 10. AT\&T Foundation & TX & $56,864,091$ & $56,864,446$ & $111,872,390$ & $12 / 31 / 2008$ \\
\hline 11. Johnson \& Johnson Family of Companies Contribution Fund & NJ & $54,757,597$ & $54,757,597$ & $5,335,269$ & $12 / 31 / 2008$ \\
\hline 12. BP Foundation & $\mathrm{IL}$ & $53,751,230$ & $54,633,140$ & $147,071,229$ & $12 / 31 / 2008$ \\
\hline 13. Pfizer Foundation & NY & $42,466,604$ & $45,467,117$ & $210,342,315$ & $12 / 31 / 2008$ \\
\hline 14. UPS Foundation & GA & $41,826,486$ & $41,844,032$ & $6,965,699$ & $12 / 31 / 2008$ \\
\hline 15. Caterpillar Foundation & IL & $38,496,803$ & $38,787,032$ & $50,297,506$ & $12 / 31 / 2008$ \\
\hline 16. MetLife Foundation & NY & $38,496,662$ & $48,023,653$ & $114,169,913$ & $12 / 31 / 2008$ \\
\hline 17. Coca-Cola Foundation & GA & $36,743,015$ & $36,743,015$ & $45,051,312$ & $12 / 31 / 2008$ \\
\hline 18. Intel Foundation & OR & $36,186,253$ & $36,186,253$ & $60,489,595$ & $12 / 31 / 2008$ \\
\hline 19. Merck Company Foundation & NJ & $36,002,032$ & $36,498,615$ & $333,730,521$ & $12 / 31 / 2008$ \\
\hline 20. Blue Shield of California Foundation & $\mathrm{CA}$ & $29,831,775$ & $35,171,849$ & $68,216,618$ & $12 / 31 / 2008$ \\
\hline 21. PepsiCo Foundation & NY & $29,360,470$ & $29,612,926$ & $53,482,403$ & $12 / 31 / 2008$ \\
\hline 22. Abbott Fund & IL & $28,979,654$ & $32,195,611$ & $208,812,145$ & $12 / 31 / 2008$ \\
\hline 23. Eli Lilly and Company Foundation & IN & $28,768,093$ & $28,768,093$ & $63,871,962$ & $12 / 31 / 2008$ \\
\hline 24. Merrill Lynch \& Co. Foundation & NY & $28,285,542$ & $28,800,629$ & $53,786,957$ & $12 / 31 / 2008$ \\
\hline 25. Alcoa Foundation & PA & $26,193,332$ & $27,467,025$ & $392,033,495$ & $12 / 31 / 2008$ \\
\hline
\end{tabular}

*The Wal-Mart Foundation (AR) ranked third in 2007, was omitted from the list because updated fiscal information was not available. List excludes corporate operating foundations.

1 Includes grants, scholarships, and employee matching gifts; excludes set-asides, loans, PRIs, and program expenses.

${ }^{2}$ Qualifying distributions are the expenditures used in calculating the required 5 percent payout; includes total giving, as well as reasonable administrative expenses, set-asides, PRIs, operating program expenses, and amount paid to acquire assets used directly for charitable purposes.

\section{The Impact of Foundations Established by Pharmaceutical Corporations}

The vast majority of corporate foundations are established as private non-operating foundations, with a principal focus on making grants to organizations for charitable purposes. Corporations may also choose to set up private operating foundations, although this is far less common. Generally, operating foundations are established to conduct research or provide a direct service. However, in the case of many of the largest corporate operating foundations, most of their charitable support takes the form of giving medicine to individuals in need. Between 1996 and 2007, thirteen pharmaceutical manufacturers established operating foundations to distribute medicine to patients with financial hardships (primarily within the United States). ${ }^{1}$ In addition, one pharmaceutical manufacturer established a non-operating corporate foundation for this purpose in the early 1990s. Together, these fourteen "pharmaceutical foundations" provided $\$ 3.1$ billion in in-kind support in 2008.
In-kind giving of medicines by some of these new pharmaceutical foundations may simply represent a shift from in-kind giving through corporate direct giving programs. Observers of the field may be surprised to learn that contributions of product are counted as part of foundations' total giving. In fact, other types of private foundations occasionally make gifts of works of art, land, or other noncash items, which are assigned a monetary value and counted toward total giving. However, nothing in the prior history of the nation's foundation community approaches the scale of product giving by this handful of foundations.

${ }^{1}$ In addition to providing pharmaceuticals to patients in need, one of these foundations, the Boehringer Ingelheim Cares Foundation, also provides monetary support to organizations involved with arts and culture, education, health, disaster relief, and human services. 


\section{Corporations' Share of All Private Giving}

Individuals account for the vast majority of private giving, followed by independent and community foundations, and then corporations and corporate foundations. Nonetheless, corporations and corporate foundations provide an essential share of support. Giving USA estimated overall corporate contributions in 2008 , including both foundation and direct corporate giving, at $\$ 14.5$ billion. According to the Foundation Center, corporate foundation giving of $\$ 4.6$ billion represented 32 percent of all corporate contributions, up from 28 percent in 2007 . However, if corporate foundation giving is combined with the in-kind medication giving by operating foundations established by pharmaceutical manufacturers, the 2008 share would rise to over 50 percent. (For more details on these grantmakers, see "The Impact of Foundations Established by Pharmaceutical Corporations.”)
Generally, corporate foundation giving represents cash contributions, while a notable portion of corporate direct giving and giving through operating foundations may reflect in-kind gifts of product. Therefore, if only cash giving were being tracked, corporate foundations would account for a larger share of overall corporate support.

Historically, corporate giving as a share of companies' pre-tax profits-excluding giving by corporate operating foundations-reached a record 2 percent in 1986. Following that peak, corporate giving fluctuated between 1 and 1.6 percent of pre-tax profits until 2004, when the share had dropped to below 1 percent. It fell below 1 percent again in 2006 and 2008.

\section{Summary 2008 Statistics for Corporate Foundations, continued}

\section{Companies in banking and finance accounted for the largest share of corporate foundation giving in 2008}

\begin{tabular}{|c|c|c|c|c|c|}
\hline Industrial Classification & $\begin{array}{l}\text { Number of } \\
\text { Foundations }\end{array}$ & $\%$ & $\begin{array}{l}\text { Total } \\
\text { Giving1 }\end{array}$ & $\%$ & $\begin{array}{c}\text { Average } \\
\text { Giving per } \\
\text { Foundation }\end{array}$ \\
\hline Chemicals & 53 & 1.9 & $\$ 109,986$ & 2.4 & $\$ 2,075$ \\
\hline Computers/Office Equipment & 17 & 0.6 & 47,648 & 1.0 & 2,803 \\
\hline Food and Agriculture & 112 & 4.1 & 195,210 & 4.3 & 1,743 \\
\hline $\begin{array}{l}\text { Industrial and Commercial } \\
\text { Machinery (Not Computer) }\end{array}$ & 168 & 6.1 & 342,681 & 7.5 & 2,040 \\
\hline Paper and Like Products & 34 & 1.2 & 32,966 & 0.7 & 970 \\
\hline Petroleum/Gas/Mining & 53 & 1.9 & 203,623 & 4.5 & 3,842 \\
\hline Pharmaceuticals & 34 & 1.2 & 405,734 & 8.9 & 11,933 \\
\hline Primary Metals & 40 & 1.5 & 43,911 & 1.0 & 1,098 \\
\hline Printing/Publishing/Media & 81 & 3.0 & 70,186 & 1.5 & 866 \\
\hline Textiles and Apparel & 75 & 2.7 & 46,628 & 1.0 & 622 \\
\hline Transportation Equipment & 73 & 2.7 & 128,149 & 2.8 & 1,755 \\
\hline Other Manufacturing & 277 & 10.1 & 271,906 & 5.9 & 982 \\
\hline Total Manufacturing & 1,017 & 37.0 & $\$ 1,898,628$ & 41.5 & $\$ 1,867$ \\
\hline Banking and Finance & 484 & 17.6 & $\$ 1,143,234$ & 25.0 & $\$ 2,362$ \\
\hline Insurance & 161 & 5.9 & 470,753 & 10.3 & 2,924 \\
\hline Retail and Wholesale Trade & 366 & 13.3 & 361,128 & 7.9 & 987 \\
\hline Telecommunications & 43 & 1.6 & 152,654 & 3.3 & 3,550 \\
\hline Transportation & 35 & 1.3 & 72,905 & 1.6 & 2,083 \\
\hline Utilities & 103 & 3.8 & 174,540 & 3.8 & 1,695 \\
\hline Other Services & 518 & 18.9 & 291,773 & 6.4 & 563 \\
\hline Total Nonmanufacturing & 1,710 & 62.3 & $\$ 2,666,988$ & 58.4 & $\$ 1,560$ \\
\hline Unspecified & 18 & 0.7 & 4,746 & 0.1 & \$2 264 \\
\hline Total & 2,745 & 100.0 & $\$ 4,570,362$ & 100.0 & $\$ 1,665$ \\
\hline
\end{tabular}

Note: Dollars in thousands. Categories are based on the Conference Board's classification of corporations using Standard Industrial Classification codes.

1 Includes grants, scholarships, and employees matching gifts; excludes set-asides, loans, PRIs, and program expenses.

\section{Corporate giving accounted for 5 percent of private philanthropic giving in 2008}

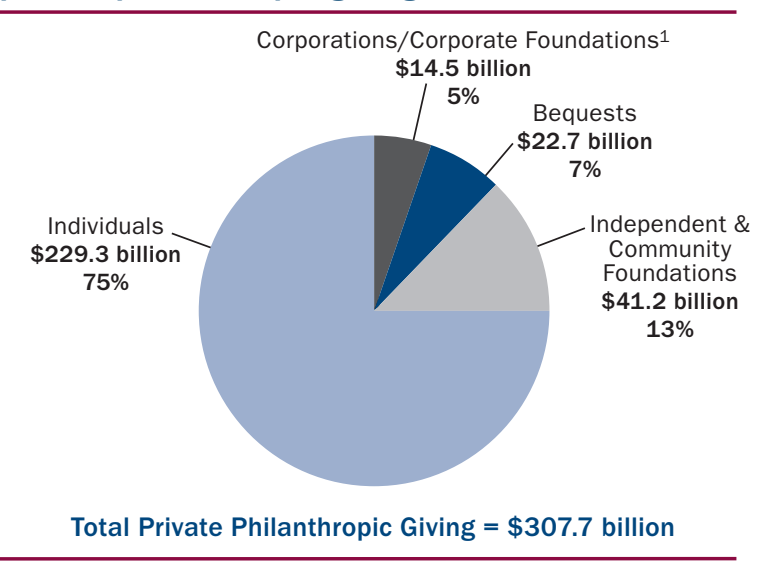

Note: Based on data from Giving USA Foundation, Giving USA 2009, ed. by M. Brown, Illinois: Giving USA Foundation, 2009.

1 Of total corporate giving for 2008 , $\$ 4.6$ billion (32\%) was paid through corporate foundations. 
Corporate Foundations by State, 2008

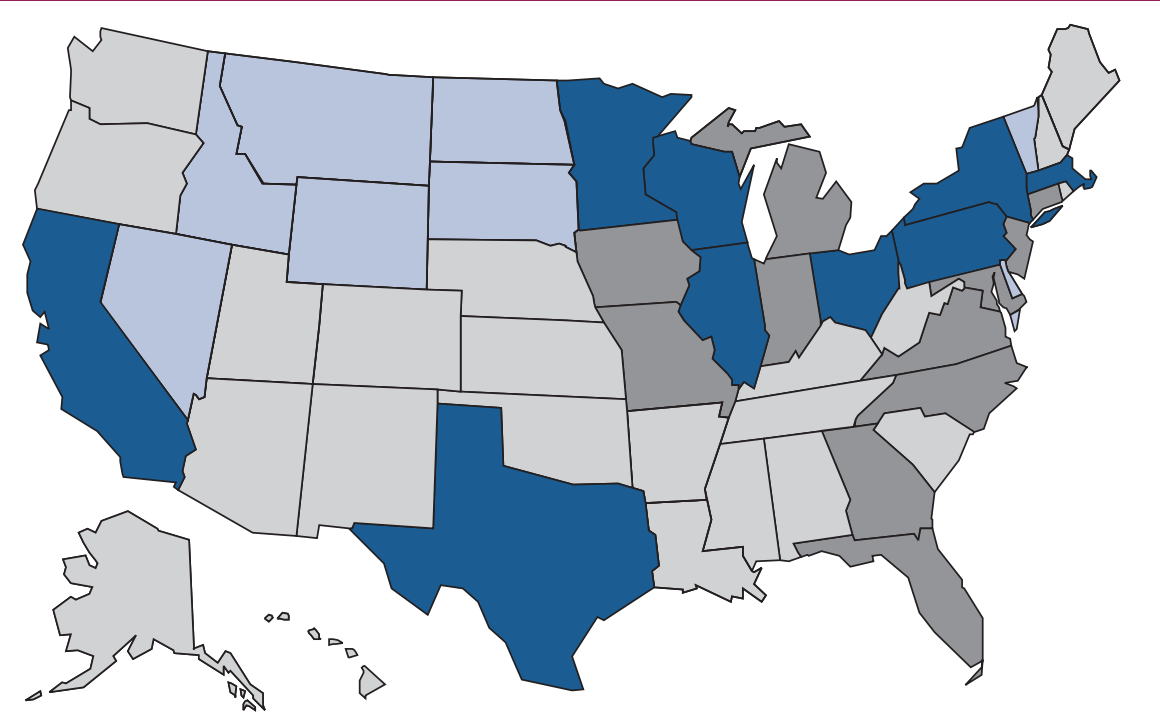

Total Corporate Foundations $=2,745$

$100+\quad 40-$ under $100 \quad 10-$ under $40 \quad$ Under 10

The Northeast accounted for the largest share of corporate foundation giving in 2008

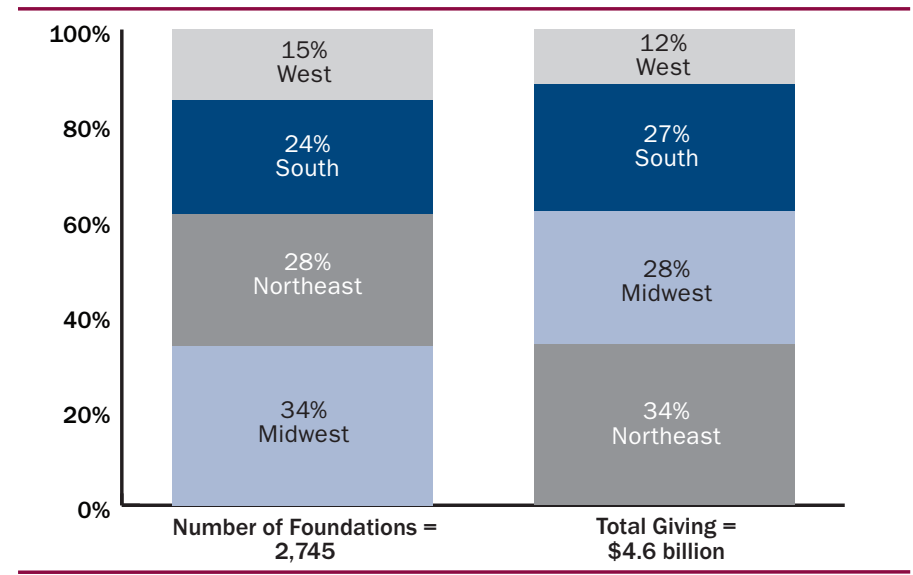

Note: Giving includes grants, scholarships, and employee matching gifts; excludes set-asides, loans, PRIs, and program expenses. Excludes giving by corporate operating foundations. Due to rounding, figures may not add up.
20 percent of corporate foundations reported more than $\$ 1$ million in giving in 2008

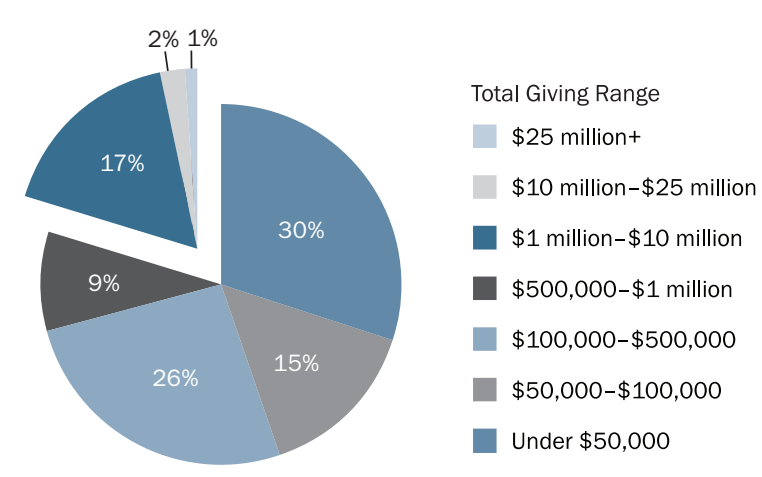

Percent of Number of Foundations

Note: Based on total giving by 2,745 grantmaking corporate foundations. Excludes giving by corporate operating foundations.

More than one-quarter of corporate foundations have been established in the 2000s

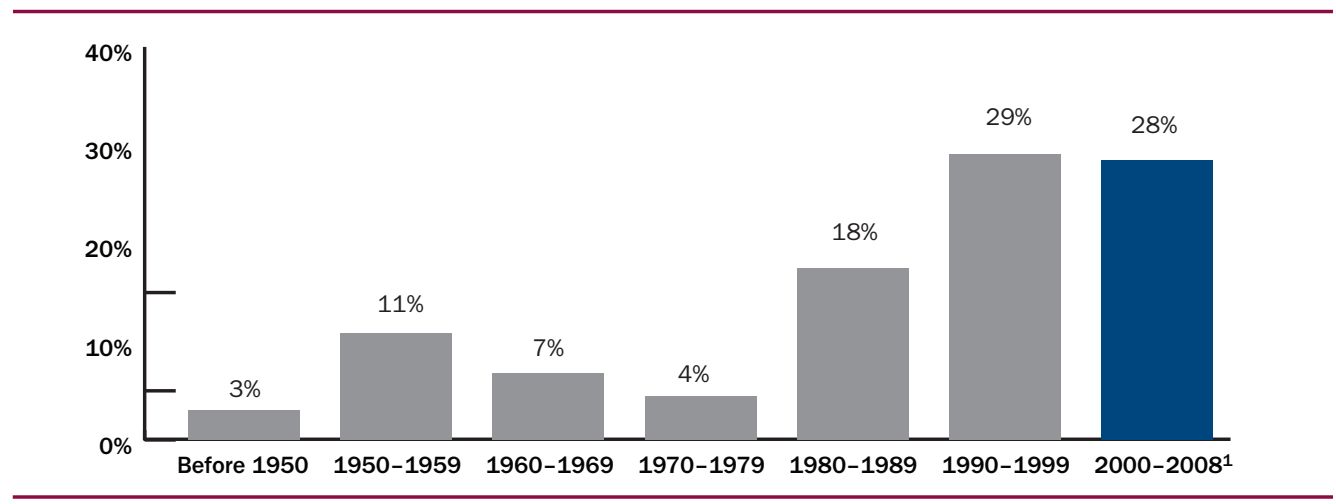

Note: Excludes 266 grantmaking corporate foundations that lack establishment information.

1Data incomplete for the period 2000-2008. 
